\title{
KERENTANAN RELATIF TEPUNG SORGUM TERHADAP KUMBANG TEPUNG MERAH (Tribolium castaneum Herbst)
}

\section{Susceptibility Relative of Sorghum Flours against Red Flour Beetle (Tribolium castaneum Herbst)}

\author{
Hasan Hendrival* dan Riska Amanda \\ Program Studi Agroekoteknologi, Fakultas Pertanian, Universitas Malikussaleh \\ Jalan Banda Aceh-Medan, Kampus Utama Reuleut Muara Batu \\ Kabupaten Aceh Utara 24355
}

*Alamat Korespondensi: hendrival@unimal.ac.id

\begin{abstract}
ABSTRAK
Penelitian bertujuan untuk mengevaluasi kerentanan relatif tepung sorgum terhadap infestasi T. castaneum selama masa penyimpanan. Penelitian menggunakan Rancangan Acak Kelompok, dengan perlakuan 6 jenis tepung sorgum dan 4 ulangan. Jenis tepung sorgum yang digunakan meliputi varietas sorgum Kawali, Numbu, Super-1, Super-2, Suri-3, dan Suri-4. Sepuluh pasang imago T. castaneum diujicobakan pada setiap jenis tepung sorgum. Variabel pengamatan meliputi jumlah $\mathrm{F} 1$, median waktu perkembangan $T$. castaneum, bobot 100 imago, persentase susut bobot tepung, dan indeks kerentanan. Hasil penelitian menunjukkan bahwa tepung sorgum dari varietas Super-1 tergolong moderat sampai rentan, sedangkan varietas Super-2 dan Suri-3 tergolong rentan, varietas Kawali dan Suri-4 tergolong sangat rentan, dan varietas Numbu tergolong rentan sampai sangat rentan terhadap T. castaneum. Kerentanan tepung sorgum dipengaruhi oleh jumlah F1, median waktu perkembanngan $T$. castaneum, dan persentase susut bobot tepung.
\end{abstract}

Kata kunci: Tribolium castaneum, indeks kerentanan, varietas sorgum, tepung sorgum

\section{ABSTRACT}

The susceptibility study of sorghum flours to Tribolium castaneum infestation was done during storage. Randomized complete block design with six sorghum flours viz. Variety of Kawali, Numbu, Super-1, Super-2, Suri3, and Suri-4 was tested. Each treatment was replicated four times. Ten pairs of imago T. castaneum were infested in each type of sorghum flours. The observed variables were number of F1 progeny T. castaneum, median development time T. castaneum, weight 100 adult, percentage weight loss, and susceptibility index. The results showed that sorghums flour of Super-1 varieties was moderate to susceptible, whereas Super-2 and Suri-3 varieties were susceptible, Kawali and Suri-4 varieties were very susceptible, and Numbu varieties were susceptible to very susceptible on T. castaneum. The susceptibility of sorghum flour wass influenced by number of F1 progeny T. castaneum, median development time of T. castaneum and flours weight loss percentage.

Key words: Tribolium castaneum, susceptibility index, sorgum variety, sorghum flours

\section{PENDAHULUAN}

Sorgum merupakan serealia yang memiliki kandungan karbohidrat dan protein yang tinggi (Budijanto dan Yuliyanti, 2012) serta memiliki potensi untuk dikembangkan di Propinsi Aceh sebagai pangan alternatif selain beras, pakan ternak, dan bioenergi (Dewi dan Yusuf, 2017). Biji sorgum berpotensi tinggi untuk diolah menjadi tepung karena biji sorgum yang memiliki nilai gizi yang baik serta bermanfaat sebagai bahan substitusi tepung terigu. Pengembangan tepung sorgum memiliki prospektif yang tinggi untuk menyediakan karbohidrat karena harga sorgum yang relatif murah, umur tanam pendek, daya adaptasi terhadap lahan tinggi, serta biaya produksinya rendah (Suarni dan Patong, 2009). Agroindustri industri berbasis 
tepung yang memiliki peluang untuk primer (Kayode et al., 2014). Serangan berat berkembang di masa yang akan datang. yang disebabkan oleh $T$. castaneum Peningkatan hasil industri tepung dengan menyebabkan komoditas tercemar oleh kualitas yang optimal perlu diikuti dengan eksuvia, kotoran potongan tubuh dari $T$. penanganan pascapanen yang baik, agar laju castaneum yang telah mati, dan ekskresi yang kerusakan dapat ditekan. Selama menghasilkan benzokuinon sehingga penyimpanan komoditas pertanian seperti komoditas tersebut tidak layak untuk tepung dapat mengalami kerusakan baik dikonsumsi dan menyebabkan tepung kuantitas maupun kualitas, salah satu berwarna coklat (Hodges et al., 1996; penyebab kerusakan tepung selama di Campbell and Runnion, 2003; Kayode et al., penyimpanan adalah serangan serangga hama 2014).

seperti Tribolium castaneum.

Kumbang tepung merah Tribolium castaneum merupakan hama sekunder yang tersebar luas di daerah subtropis dan tropis serta menyerang komoditas pertanian di penyimpanan (Kayode et al., 2014). T. castaneum banyak ditemukan di daerah tropis seperti Indonesia. T. castaneum dikenal sebagai hama utama di tempat pengolahan dan penyimpanan produk pertanian seperti pabrik tepung dan pasar (Mewis and Ulrichs, 2001; Verheggen et al., 2007) serta biskuit (Odeyemi et al., 2005). Imago dan larva $T$. castaneum selalu merusak tepung seperti tepung gandum, jagung, beras, kacang hijau, kentang, panir, ketan putih, tapioka, sagu, dan dedak (Hendrival et al., 2016). T. castaneum memiliki kemampuan yang rendah untuk merusak serealia atau produkpertanian lainnya yang masih utuh, tetapi memiliki kemampuan reproduksi yang cepat pada serealia yang telah digiling menjadi tepung atau serealia yang telah dirusak oleh hama

Tingkat preferensi $T$. Castaneum yang berbeda terhadap berbagai jenis tepung sehingga menentukan kerentanan pada jenis tepung tersebut selama penyimpanan (Kheradpir, 2014; Hendrival et al., 2016). Perbedaan kerentanan tepung terhadap $T$. castaneum dapat terjadi pada jenis tepung dari pengolahan biji-bijian yang berbeda (Ajayi and Rahman, 2006; Hendrival et al., 2016). Telah diketahui bahwa serealia dan pengolahannya dari jenis dengan varietas yang sama memiliki tingkat kerentanan yang berbeda terhadap hama pascapanen selama penyimpanan (Bamaiyi et al., 2007; Ladang et al., 2008). Penelitian kerentanan tepung sorgum dari varietas yang berbeda terhadap infestasi T. castaneum perlu dilakukan karena berkaitan dengan pertumbuhan populasi dan periode perkembangan $T$. castaneum serta susut bobot tepung sorgum selama penyimpanan.Informasi tentang kerentanan tepung sorgum terhadap infestasi $T$. castaneum masih terbatas ketersediaannya. 
Penelitian bertujuan untuk mengevaluasi kerentanan relatif tepung sorgum terhadap infestasi $T$. castaneum selama masa penyimpanan.

\section{METODE PENELITIAN}

Satuan percobaan dari penelitian disusun dalam Rancangan Acak Lengkap dengan perlakuan jenis tepung sorgum dan setiap perlakuan diulang sebanyak empat kali. Jenis tepung sorgum yang digunakan dari sorgum varietas Kawali, Numbu, Super-1, Super-2, Suri-3, dan Suri-4. Semua varietas jagung diperoleh dari Balai Penelitian Tanaman Serelia, Maros, Sulawesi Selatan.

Butiran sorgum disosoh untuk memisahkan kulit dari butiran sorgum. Penyosohan dilakukan pada $1 \mathrm{~kg}$ butiran sorgum sebanyak satu kali untuk mendapatkan rendemen butiran sorgum. Proses pembuatan tepung sorgum diawali dengan penambahan air sebanyak $25 \%$ dari berat butiran sorgum yang telah disosoh ( 250 $\mathrm{ml}$ per $1 \mathrm{~kg}$ butiran). Penambahan air untuk melunakan endosperm pada biji sehingga mudah hancur pada saat penggilingan sehingga menghasilkan tepung yang lebih halus. Butiran sorgum yang telah dicampurkan dengan disimpan dalam stoples plastik selama 12 jam, selanjutnya proses penggilingan butiran sorgum menjadi tepung dengan menggunakan mesin penggilingan tepung.
Pembiakkan serangga $T$. castaneum dilakukan pada tepung gandum dengan kandungan protein mencapai $20 \%$ dan kondisi suhu $29-32{ }^{0} \mathrm{C}$ dan $\mathrm{RH} 70-75 \%$. Imago $T$. castaneum diinfestasi ke dalam stoples pemeliharaan dengan tingkat populasi 50 ekor imago dengan $250 \mathrm{~g}$ tepung gandum. Pembiakkan T. castaneum dilakukan dari peletakan telur sampai menjadi pupa. Pengayakan dilakukan untuk memisahkan imago T. castaneum awal dari media tepung gandum. Media tepung gandum tersebut diinkubasikan kembali sampai muncul pupa $T$. castaneum. Imago $T$. castaneum awal tersebut diinfestasi ke dalam stoples pemeliharaan yang berisikan media tepung gandum yang baru untuk pemeliharaan selanjutnya. Imago jantan dan betina dipisahkan pada stadia pupa yang diamati melalui mikroskop stereo (Hendrival et al., 2016).

Tepung sorgum yang digunakan dalam penelitian sebanyak $100 \mathrm{~g}$ dimasukkan ke dalam wadah plastik dengan ukuran tinggi 6 $\mathrm{cm}$ dan diameter $8 \mathrm{~cm}$ serta diberikan lubang aerasi dengan diameter $4 \mathrm{~cm}$ yang dilapisi kain kasa pada tutup stoples plastik. Imago $T$. castaneum yang berumur 7-15 hari dari hasil pembiakkan diinfestasikan dengan tingkat populasi awal yaitu 10 pasang imago ke dalam $100 \mathrm{~g}$ tepung dan disimpan selama penelitian.

Kerentanan tepung diadaptasikan berdasarkan indeks kerentanan yang 
ditentukan menggunakan metode Dobie (1974). Indeks kerentanan tepung ditentukan berdasarkan jumlah F1 dan median waktu perkembangan $T$. castaneum. Jumlah F1 pada tepung ditentukan setelah tepung dan imago diinkubasi selama dua minggu, selanjutnya imago-imago tersebut dikeluarkan dari wadah penelitian dan dihitung setiap harinya sampai 40 hari setelah infestasi. Pengamatan median waktu perkembangan dilakukan setiap hari untuk mengetahui kemunculan $T$. castaneum turunan pertama sejak 20 hari setelah infestasi sampai pertambahan populasi mencapai 50\% dari populasi awal. Pengelompokan tingkat kerentanan tepung sorgum berdasarkan nilai indeks kerentanan yaitu resisten (berkisar antara 0-3), moderat (berkisar antara 4-7), rentan (berkisar antara 8-10), dan sangat rentan (>11).Perhitungan indeks kerentanan diadaptasi menggunakan rumus Dobie (1974) yaitu.

Indeks kerentanan $=100 \times \frac{\left(\log _{\mathrm{e}} F\right)}{D}$

Keterangan:

$\mathrm{F}=$ total jumlah $\mathrm{F} 1$ imago

$\mathrm{D}=$ median waktu perkembangan

Penghitungan bobot 100 imago dilakukan dengan cara menimbang sebanyak 100 ekor imago yang masih hidup dari setiap jenis tepung sorgum dan ditimbang dengan menggunakan timbangan analitik. Bobot 100 imago dihitung dalam satuan $\mathrm{g}$.

Penghitungan susut bobot tepung dilakukan pada akhir penyimpanan
tepung.Bobot tepung yang hilang selama penelitian dianggap sebagai bobot yang susut karena dikonsumsi oleh larva dan imago. Penghitungan susut bobot tepung menggunakan rumus yaitu persentase susut bobot tepung $=[$ (bobot tepung awal-bobot tepung akhir)/bobot tepung awal] x100\%.

Data hasil pengamatan dianalisis dengan analisis ragam dan uji Duncan's Multiple Range Test (DMRT) taraf 0,05. Pengukuran kekuatan hubungan antara indeks kerentanan dengan jumlah F1, median waktu perkembangan, bobot 100 imago, dan persentase susut bobot tepung ditentukan dengan analisis korelasi.

\section{HASIL DAN PEMBAHASAN}

\section{Jumlah F1}

Hasil analisis ragam menunjukkan bahwa perbedaan jenis tepung sorgum berpengaruh sangat nyata terhadap jumlah F1, median waktu perkembangan, bobot 100 imago, persentase susut bobot tepung, dan indeks kerentanan. Parameter jumlah F1, median waktu perkembangan, bobot 100 imago, persentase susut bobot tepung, dan indeks kerentanan tepung sorgum disajikan pada Tabel 1 dan Tabel 2. Jumlah F1 paling banyak dijumpai pada tepung sorgum varietas Suri-4 yaitu 607,25 imago/100 g, namun tidak berbeda nyata dengan tepung dari varietas Kawali, Numbu, dan Super 2. Jumlah F1 pada tepung sorgum varietas Suri 3 mencapai 452,75 imago/100 g. Jumlah F1 paling rendah dijumpai pada tepung sorgum varietas Super- 
1 sebesar 193,75 imago/100 g. Tepung perkembangan yang tidak berbeda sorgum dari varietas Suri-4, Kawali, Numbu, nyata.Berdasarkan data tersebut diketahui dan Super-2 secara nyata dapat meningkatkan bahwa semua jenis tepung sorgum merupakan jumlah F1 dibandingkan dengan tepung makanan bagi larva dan imago (Tabel 1). sorgum dari varietas Suri-3 dan Super-1 Median waktu perkembangan merupakan (Tabel 1). Jumlah F1 menunjukkan kesesuaian antara $T$. castaneum dengan tepung sebagai makanannya.Jumlah F1 dipengaruhi oleh kualitas tepung. Kualitas tepung tersebut meliputi sifat-sifat fisiologis dan kimiawi yang dapat mempengaruhi perkembangan larva dan imago.Tepung sorgum dari varietas Suri-4, Kawali, Numbu, dan Super-2 memiliki sifat-sifat fisiologis dan kimiawi yang yang disukai oleh $T$. castaneum. Hendrival et al. (2016) mengemukakan bahwa kualitas nutrisi tepung dan dedak dapat mempengaruhi pertumbuhan populasi $T$. castaneum pada tepung dan dedak selama penyimpanan.Lale et al. (2000) menyatakan bahwa pertumbuhan populasi $T$. castaneum dipengaruhi oleh kualitas makanannya.

\section{Median Waktu Perkembangan}

Median waktu perkembangan $T$. castaneum paling lama dijumpai pada tepung sorgum varietas Super-1 dan Super-2 yaitu 29,75 dan 29,50 hari. Median waktu perkembangan paling singkat dijumpai pada tepung sorgum varietas Suri-4 yaitu 24,75 hari, namun tidak berbeda nyata dengan varietas Kawali. Tepung sorgum varietas Numbu dan Suri-3 memiliki median waktu parameter untuk menentukan kerentanan tepung sorgum terhadap $T$. castaneum. Median waktu perkembangan yang singkat, mengindikasikan bahwa tepung sorgum menjadi rentan terhadap $T$. castaneum. Hendrival et al. (2016) mengemukakan bahwa median waktu perkembangan $T$. castaneum yang singkat pada jenis tepung menyebabkan jenis tepung tersebut rentan terhadap $T$. castaneum selama penyimpanan.

\section{Kerentanan Tepung}

Nilai indeks kerentanan tepung sorgum berkisar antara 7,67-11,24. Nilai indeks kerentanan paling rendah dijumpai pada tepung sorgum varietas Super-1 yaitu 7,67 dan tergolong kategori moderat-rentan. Indeks kerentanan paling tinggi dijumpai pada varietas Suri-4 dan Kawali yaitu 11,09 dan 11,24 serta kedua tergolong kategori sangat rentan.Indeks kerentanan diketahui bahwa tepung sorgum varietas Super-2 dan Suri-3 tidak berbeda nyata dan tergolong kategori rentan. Indeks kerentanan tepung sorgum varietas Numbu yaitu 10,41 dan tergolong katagori rentan-sangat rentan terhadap infestasi $T$. castaneum selama penyimpanan tepung sorgum (Tabel 2). 
Tabel 1. Parameter jumlah F1, median waktu perkembangan, bobot 100 imago, persentase susut bobot tepung, indeks kerentanan dan kategori kerentanan tepung sorgum

\begin{tabular}{lcccc}
\hline Jenis tepung & $\begin{array}{c}\text { Jumlah F1 } \\
\text { (imago/100 g tepung) }\end{array}$ & $\begin{array}{c}\text { Median waktu } \\
\text { perkembangan } \\
\text { (hari) }\end{array}$ & $\begin{array}{c}\text { Bobot } 100 \text { imago } \\
(\mathrm{g})\end{array}$ & $\begin{array}{c}\text { Persentase } \\
\text { susut bobot } \\
(\%)\end{array}$ \\
\hline Kawali & $594,25 \mathrm{a}$ & $25,00 \mathrm{c}$ & $0,2183 \mathrm{a}$ & $18,98 \mathrm{a}$ \\
Numbu & $574,75 \mathrm{a}$ & $26,50 \mathrm{~b}$ & $0,2194 \mathrm{a}$ & $18,55 \mathrm{ab}$ \\
Super 1 & $193,75 \mathrm{c}$ & $29,75 \mathrm{a}$ & $0,1994 \mathrm{~b}$ & $6,58 \mathrm{c}$ \\
Super 2 & $526,00 \mathrm{ab}$ & $28,75 \mathrm{a}$ & $0,2231 \mathrm{a}$ & $17,17 \mathrm{ab}$ \\
Suri 3 & $452,75 \mathrm{~b}$ & $27,25 \mathrm{~b}$ & $0,2010 \mathrm{~b}$ & $14,73 \mathrm{~b}$ \\
Suri 4 & $607,25 \mathrm{a}$ & $24,75 \mathrm{c}$ & $0,2273 \mathrm{a}$ & $21,68 \mathrm{a}$ \\
F hitung & $22,47 * *$ & $36,00 * *$ & $7,57^{* *}$ & $19,16^{* *}$ \\
\hline
\end{tabular}

Keterangan: angka yang diikuti oleh huruf yang sama tidak berbeda nyata berdasarkan uji $D M R T p=0,05$.

Tabel 2. Indeks kerentanan dan kategori kerentanan tepung sorgum terhadap infestasi $T$. castaneum

\begin{tabular}{lcl}
\hline Jenis tepung & Indeks kerentanan & \multicolumn{1}{c}{ Kategorikerentanan } \\
\hline Kawali & $11,09 \mathrm{a}$ & Sangat rentan \\
Numbu & $10,41 \mathrm{~b}$ & Rentan-sangat rentan \\
Super 1 & $7,67 \mathrm{~d}$ & Moderat-rentan \\
Super 2 & $9,46 \mathrm{c}$ & Rentan \\
Suri 3 & $9,75 \mathrm{c}$ & Rentan \\
Suri 4 & $11,24 \mathrm{a}$ & Sangat rentan \\
\hline F hitung & $42,30^{* *}$ & \\
\hline
\end{tabular}

Keterangan: Angka yang diikuti oleh huruf yang sama tidak berbeda nyata berdasarkan uji $D M R T p=0,05$.

Tabel 3. Matriks korelasi antara jumlah F1, median waktu perkembangan, bobot 100 imago, persentase susut bobot dengan kerentanan tepung sorgum terhadap infestasi $T$. castaneum

\begin{tabular}{|c|c|c|c|c|c|}
\hline Karakter & $\begin{array}{c}\text { Jumlah } \\
\text { F1 }\end{array}$ & $\begin{array}{l}\text { Median waktu } \\
\text { perkembangan }\end{array}$ & $\begin{array}{c}\text { Bobot } 100 \\
\text { imago }\end{array}$ & $\begin{array}{l}\text { Persentase } \\
\text { susut bobot }\end{array}$ & $\begin{array}{c}\text { Indeks } \\
\text { kerentanan }\end{array}$ \\
\hline Jumlah F1 & 1 & & & & \\
\hline $\begin{array}{l}\text { Median waktu } \\
\text { perkembangan }\end{array}$ & $-0,816^{*}$ & 1 & & & \\
\hline Bobot 100 imago & $0,829 *$ & $-0,586$ & 1 & & \\
\hline Persentase susut bobot & $0,988 * *$ & $-0,838^{*}$ & $0,860^{*}$ & 1 & \\
\hline Indeks kerentanan & $0,948 * *$ & $-0,957 * *$ & 0,727 & $0,954 * *$ & 1 \\
\hline
\end{tabular}

Keterang: $* *=$ berkorelasi sangat nyata $(\mathrm{p}<0,01)$ dan $*=$ berkorelasi nyata $(\mathrm{p}<0,05)$.

Hasil analisis korelasi menunjukkan bahwa terdapat korelasi positif sangat nyata antara jumlah F1 T. castaneum dan korelasi negatif yang sangat nyata dengan median waktu perkembangan $T$. castaneum dengan kerentanan jenis tepung sorgum (Tabel 3).
Korelasi antar karakter menunjukkan bahwa kerentanan tepung sorgum ditentukan oleh jumlah F1 T. castaneum dan median waktu perkembangan $T$. castaneum. Peningkatan jumlah F1 T. castaneum dan median waktu perkembangan $T$. castaneum yang singkat 
dapat menyebabkan peningkatan indeks kerentanan tepung terhadap $T$. castaneum. Peningkatan indeks kerentanan menunjukkan bahwa jenis tepung sorgum mudah diserang oleh hama T. castaneum selama penyimpanan.

Kerentanan tepung sorgum ditentukan oleh jumlah F1 $T$. castaneum dan median waktu perkembangan. Jenis tepung sorgum yang tergolong rentan ditentukan oleh jumlah F1 T. castaneum yang banyak dan median waktu perkembangan $T$. castaneum yang singkat. Hasil penelitian Hendrival et al. (2016) menunjukkan bahwa kerentanan tepung ditentukan oleh populasi $T$. castaneum dan median waktu perkembangan $T$. castaneum pada tepung tersebut. Jumlah F1 $T$. castaneum yang banyak dan median waktu perkembangan yang singkat menyebabkan tepung menjadi rentan terhadap T. castaneum. Kabir et al. (2010) mengemukakan bahwa jenis tepung sorgum yang tergolong rentan terhadap infestasi $T$. castaneum ditentukan oleh populasi $T$. castaneum yang tinggi, sedangkan kurang rentan ditentukan oleh populasi $T$. castaneum yang rendah.Indeks kerentanan juga dipengaruhi oleh faktor fisik dan kimia dari tepung karena dapat mempengaruhi kemampuan akses makan dari serangga.

\section{Bobot Imago}

Bobot 100 imago pada tepung sorgum varietas Kawali, Numbu, Super2, dan Suri 4 menunjukan hasil yang tidak berbeda nyata.
Bobot 100 imago paling rendah dijumpai tepung sorgum varietas Super 1, namun tidak berbeda nyata dibandingkan dengan tepung sorgum varietas Suri 3 (Tabel 1). Perbedaan bobot imago dipengaruhi oleh kenaikan bobot pada fase larva, tetapi kemudian mengalami penurunan pada fase pupa dan fase imago. Kenaikan bobot tubuh pada fase larva disebabkan oleh aktifitas makan yang tinggi, sedangkan penurunan bobot yang terjadi pada fase pupa dan imago disebabkan oleh penurunan aktifitas makan dan proses perubahan bentuk, serta aktifitas reproduksi T. castaneum.

\section{Persentase Susut Bobot}

Aktivitas makan dari larva dan imago secara nyata menyebabkan peningkatan persentase susut bobot tepung sorgum dari berbagai varietas. Persentase susut bobot paling tinggi dijumpai pada tepung sorgum varietas Suri 4 yaitu 21,68\%, namun tidak berbeda nyata dengan tepung varietas Kawali, Numbu, dan Super 2. Persentase susut bobot paling rendah dijumpai pada tepung sorgum varietas Super 1 yaitu 6,58\%. Persentase susut bobot pada tepung sorgum varietas Suri 3 mencapai 14,73\% (Tabel 1). Larva dan imago sangat menyukai tepung sorgum sebagai sumber makanan terutama dari varietas Suri 4, Kawali, Numbu, dan Super 2 sehingga persentase susut bobot lebih tinggi pada keempat jenis tepung sorgum tersebut. Hasil penelitian Kayode et al. (2014) menunjukkan bahwa tepung sorgum dan 
gandum tergolong rentan terhadap insfestasi T. castaneum selama penyimpanan. Hasil penelitian Jamil and Aslam (2000) menunjukkan bahwa terjadi penurunan bobot tepung gandum dari berbagai varietas akibat dari aktivitas makan T. castaneum. Persentase susut bobot tepung gandum berkisar antara 3,08-13,05\%. Aktivitas makan yang dilakukan oleh larva dan imago T. castaneum menyebabkan kehilangan bobot tepung sorgum di penyimpanan.

Persentase susut bobot tepung sorgum dipengaruhi oleh jumlah F1, median waktu perkembangan, dan bobot 100 imago. Peningkatan persentase susut bobot tepung sorgum terjadi karena didukung oleh jumlah F1 $\left(r=0,988^{* *} ; P<0,01\right)$ dan bobot 100 imago $\left(r=0,860^{*} ; P<0,05\right)$ yang mengalami peningkatan serta median waktu perkembangan $T$. castaneum yang singkat $(r$ $\left.=-0,838^{* *} ; P<0,05\right)$ (Tabel 3). Hasil penelitian Hendrival et al. (2016) menunjukkan bahwa peningkatan persentase susut bobot tepung selama penyimpanan ditentukan oleh populasi dan median waktu perkembangan T. castaneum.

Persentase susut bobot tepung mempengaruhi kerentanan tepung sorgum terhadap T. castaneum.Hasil analisis korelasi memperlihatkan bahwa terdapat korelasi positif yang sangat nyata antara indeks kerentanan dengan persentase susut bobot tepung $(r=0,954 * * ; P<0,01)$. Terjadinya peningkatan persentase susut bobot tepung menyebabkan tepung sorgum tergolong rentan terhadap $T$. castaneum selama penyimpanan.Hama $T$. castaneum tidak memiliki kemampuan untuk merusak produk bahan pangan yang masih utuh mampu berkembang biak dengan cepat pada bahan pangan yang mengalami pengolahan lanjutan menjadi tepung atau atau telah dirusak oleh hama primer lainnya (Kayode et al., 2014). Preferensi $T$. castaneum terhadap tepung sorgum sebagai sumber makanan dan oviposisi bervariasi berdasarkan varietas sorgum.Implikasi hasil penelitian bahwa semua jenis tepung sorgum terindikasi rentan terhadap infestasi $T$. castaneum selama penyimpanan dan tidak menyimpan tepung sorgum tersebut dalam jangka waktu yang lama karena menurunkan kuantitas tepung sorgum.Pengetahuan tentang kesukaan $T$. castaneum terhadap tepung sorgum dapat membantu mendeteksi kerusakan dan kerugian tepung sorgum selama penyimpanan.

\section{KESIMPULAN}

Jenis tepung sorgum memiliki tingkat kerentanan dari moderat sampai sangat rentan terhadap infestasi hama $T$. castaneum. Tepung sorgum dari varietas Super-1 tergolong moderat-rentan, sedangkan varietas Super-2 dan Suri-3 tergolong rentan, varietas Kawali dan Suri-4 tergolong sangat rentan, serta varietas numbu tergolong rentan-sangat rentan. Kerentanan tepung 
sorgum dipengaruhi oleh jumlah F1 $T$. castaneum, median waktu perkembangan, persentase susut bobot tepung.

\section{DAFTAR PUSTAKA}

Ajayi, F. A. and S. A. Rahman. 2006. Susceptibility of some staple processed meals to red flour beetle, Tribolium castaneum (Herbst)(Coleoptera: Tenebrionidae). Pakistan Journal of Biological Sciences, 9(9): 1744 - 1748.

Bamaiyi, L. J., M .C. Dike, and I. Onu. 2007. Relative susceptibility of some sorghum varieties to the rice weevil, Sitophilus oryzae L. (Coleoptera: Curculionidae). Journal of Entomology, 5: $387-392$.

Budijanto, S. dan D. Yulianti. 2012. Studi persiapan tepung sorgum (Sorghum bicolor L. Moench) dan aplikasinya pada pembuatan beras analog. Jurnal Teknologi Pertanian, 13(3): 177 - 186.

Campbell, J. F. and C. Runnion. 2003. Patch exploitation by female red flour beetles, Tribolium castaneum. Journal of Insect Science, 3: $1-8$.

Dewi, E. S. dan M. Yusuf. 2017. Potensi pengembangan sorgum sebagai pangan alternatif, pakan ternak dan bioenergi di Aceh. Jurnal Agroteknologi, 7(2): 27 32.

Dobie, P. 1974. The laboratory essessment of the inherent suscebtibility of maize variety the postharvest by Sitophilus zeamais Motschulsky (Coleoptera: Curculionidae). Journal of Stored Product Research, 10: 183 - 197.

Hendrival, Latifah, D. Saputra, dan Orina. 2016. Kerentanan jenis tepung terhadap infestasi kumbang tepung merah (Tribolium castaneum Herbst) (Coleoptera: Tenebrionidae). Jurnal Agrikultura, 27(3): 148 - 153.

Hodges, R. J., R. Robinson, and D. R. Hall. 1996. Quinone contamination of dehusked rice by Tribolium castaneum (Herbs) (Coleoptera: Tenebrionidae). Journal of Stored Product Research, 32: $31-37$.

Jamil, S. and M. Aslam. 2000. Screening of different wheat curivers (flour) against the attack of Triboliumcastaneum Herbst (Coleoptera: Tenebrionidae) under laboratory conditions. Pakistan Journal of Biological Sciences, 3(12): $2256-2259$.

Kabir, B. G. J, J. M. Turaki, and B. M. Sastawa. 2010. Susceptibility of flours of various millet types and sorghum cultivars to infestation by Tribolium castaneum (Herbst) (Coleoptera: Tenebrionidae) in different seasons. International Journal of Pure and Applied Sciences, 4(1): 39 - 46.

Kayode, O. Y., C. O. Adedire, and R. O. Akinkurolere. 2014. Influence of four cereal flours on the growth of Tribolium castaneum herbst (Coleoptera: Tenebrionidae). Ife Journal of Science, 16(3): $505-516$.

Kheradpir, N. 2014.Food preference of $T$. castaneum among four flour types. European Journal of Experimental Biology, 4(1): 436 - 439.

Ladang, Y. D., L. T. S. Ngamo, M. B. Ngassoum, P. M. Mapongmestsem, and T. Hance. 2008. Effect of sorghum cultivars on population growth and grain damages by the rice weevil, Sitophilus oryzae L. (Coleoptera: Curculionidae). African Journal of Agricultural Research, 3: 255 - 258.

Lale, N. E. S., M. Lawan, and F. A. Ajayi. 2000, Effects oftemperature and yeast supplementation on the development of Tribolium castaneum (Herbst) in wholemeal and polished flour derived from four cereals in Maiduguri, Nigeria. Anzeiger fur Schadlinskunde, 73: 89 92.

Mewis, I. and C. Ulrichs. 2001. Action of amorphous diatomaceous earth against 
different stages of the stored product pest Tribolium confusum, Tenebrio molitor, Sitophilus granarius and Plodia interpunctella. Journal of Stored Product Research, 37: 153 - 164.

Odeyemi, O. O., B. M. Oyedare, and M. O. Ashamo. 2005. Resistance of seven biscuit types to infestation by Tribolium castaneum (Herbst) (Coleoptera: Tenebrionidae). Zoological Research, 26(3): $300-304$.
Suarni dan R. Patong. 2009. Tepung sorgum sebagai bahan substitusi terigu. Jurnal Penelitian Pertanian Tanaman Pangan, 21(1): $43-47$.

Verheggen, F., C. Ryne, P. O. Olsson, L. Arnaud, G. Lognay, H. E. Hogberg, D Persson, E. Haubruge, and C. Lofstedt. 2007. Electrophysiological and behavioral activity of secondary metabolites in the confused flour beetle, Tribolium confusum. Journal of Chemical Ecology, 33: 525 - 539. 